\title{
Organic Seed Hydration-Dehydration Techniques Improve Seedling Quality of Organic Tomatoes
}

\author{
H. Özkan SIVRITEPE*, Nuray SIVRITEPE \\ Uludag University, Faculty of Agriculture, Department of Horticulture, Görükle Campus, Nilüfer, Bursa 16059, \\ Turkey; ozkan@uludag.edu.tr(*correspondingauthor);nuray@uludag.edu.tr
}

\begin{abstract}
The use of pre-sowing organic hydration-dehydration techniques to improve quality and performance of organic seeds has already been lacking in the literature as well as in the organic farming regulations of different countries. Hence, this study was conducted to investigate the effects of organic hydration (hydropriming and organic priming) and dehydration treatments on germination and early seedling growth in organic tomato seeds. Following each priming treatment, the seeds were surface dried and divided into two sub-groups. First part of the seeds was taken to the germination tests immediately while the second part was dried back until the original seed moisture content was reached before the germination tests were set up. Then, responses of organic tomato seeds to organic hydration and dehydration treatments were observed on the bases of viability (normal germination rate) and different vigour parameters such as mean germination time, germination index, seedling dry weight and seedling vigour index. When the overall data were assessed, the best results were obtained from the hydropriming and organic priming with $250 \mathrm{ppm}$ seaweed extract solution followed by both dehydration treatments in organic tomato seeds. Consequently, these results suggested that hydropriming and organic priming could be used both in seed and seedling industries to improve organic seed quality and performance. Furthermore, the results indicated that the addition of these organic hydration-dehydration protocols to the current procedures of the regulations of organic tomato production could be a useful strategy.
\end{abstract}

Keywords: Lycopersicon esculentum, Ascophyllum nodosum, hydropriming, organic priming, seed viability, seed vigour

\section{Introduction}

In seed technology, different pre-sowing treatments have been utilised to obtain fast and uniform germination or emergence. One of the most important pre-sowing treatments is known as seed priming. This advancement technique is based on seed imbibition allowing the seeds to go through the first reversible stage of germination but do not allow radical protrusion through the seed coat. Seeds keeping their desiccation tolerance are then dehydrated and can be stored until final sowing. During subsequent germination, primed seeds exhibit a faster and more synchronized germination and young seedlings are often more vigorous and tolerant to abiotic stresses than seedlings obtained from unprimed seeds (Lutts $e t$ al., 2016). Various seed priming techniques have been developed in order to invigorate seeds and alleviate the environmental stresses. These can be listed as follows (Ashraf and Foolad, 2005; Lutts et al., 2016): hydropriming (priming seeds in water), halopriming (priming seeds in inorganic salt solutions), osmopriming (priming seeds in osmotic solutions such as PEG), hormopriming (priming seeds in plant growth regulator solutions), thermopriming (priming seeds at low or high temperatures), solid matrix priming (priming seeds with solid matrices), and biopriming (priming seeds by the use of biological compounds). Moreover, organic priming with seaweed extract has also been developed (Sivritepe and Sivritepe, 2008; Sivritepe et al., 2015). Priming efficiency is affected by many factors and strongly depends on treated plant species (even cultivars within a species) and chosen priming technique. Physical and chemical factors such as osmotic and water potential, priming agent, duration, temperature, presence or absence of light, aeration, and seed condition also influence priming success and determine germination rate and time, seedling vigour, and further plant development (Hussain et al., 2006; Varier et al., 2010).

It is well known that brown seaweeds are good organic fertilizers and used in organic farming as well as in conventional plant growing. However, the costs of collection, drying and transportation of seaweeds restrict their widespread use. In Europe and North America, the seaweed most commonly utilised is Ascophyllum nodosum (Senn, 1987; Blunden, 1991). The major biologically-active compounds of the Ascophyllum 
400

nodosum extract are plant growth regulators, such as auxins and cytokinins. Studies have also strongly indicated the potential role of betaines (Blunden, 1991). Moreover, minerals, carbohydrates and antibiotics are active ingredients of the seaweed extract (SWE) (Senn, 1987).

A wide range of beneficial effects has been reported from the use of seaweed extracts, including increased crop yield and quality, resistance to frost, uptake of inorganic nutrients from the soil, resistance to stress conditions and improved seed germination and seedling establishment (Blunden, 1991; Sivritepe and Sivritepe, 2008; Craigie, 2011; Sivritepe et al., 2015; Lutts et al., 2016). Of these effects, improved seed germination is an attractive result for seed technology. Therefore, priming with SWE solutions could be a promising method for organic seeds before transferring them to organic production processes.

The choice of high quality organic seed of suitable varieties is an important key to successful organic farming, allowing for improved crop yield and quality, for crop resilience, considerate use of non-renewable resources and for increased genetic and species diversity (IFOAM, 2011). Nevertheless, the use of presowing organic hydration-dehydration techniques (to increase seed quality and performance) is not included in the organic farming regulations of USA, EU and non-EU countries such as Turkey.

Therefore, in the present study, the effects of organic seed hydration such as hydropriming (HP) and organic priming (OP) with SWE and also subsequent dehydration treatments on germination and early seedling growth were investigated in organic tomato seeds.

\section{Materials and Methods}

\section{Biologicalmaterials}

Organic certified seeds of tomato cv. 'Rio Grande' (which were obtained from Atatürk Central Horticultural Research Institute in Yalova, Turkey) had an initial moisture content of $7.4 \% \mathrm{fw}$ basis and $82.5 \%$ normal germination. Seed moisture content and germination tests were conducted as described in the ISTA Rules (ISTA, 2012). The seeds were stored in a fridge at $3{ }^{\circ} \mathrm{C}$ until required for experimentation. The seaweed (Ascophyllum nodosum) extract (Maxicrop; Maxicrop International Ltd., UK) used in organic priming experiments was purchased from a local chemical company in Bursa, Turkey. The seaweed extract was also certified organic material to use in organic farming.

\section{Experimentalprocedures}

The seeds were primed for 2 days at $20^{\circ} \mathrm{C}$ in continuously aerated distilled $\mathrm{H}_{2} \mathrm{O}$ (i.e., hydroprimed) and SWE solutions (250, 500, 1000 and $2000 \mathrm{ppm})$, i.e., organic primed. Untreated seeds were evaluated as the control. Following each priming treatment, the seeds were put in a wire mesh strainer, washed with tap water for 3 minutes and rinsed with distilled water. Then the seeds were surface dried (SD) at $25^{\circ} \mathrm{C}$ and the change in weight was determined and the final seed moisture content of each treatment group was estimated using the following equation (Sivritepe, 1992):

$c=a(100-b) /(100-d)$,

where:

$\mathrm{c}$ - is the final weight of seed $(\mathrm{g})$, a - is the initial weight of seed (g),

$\mathrm{b}$ - is the initial moisture content $(\%, \mathrm{fw})$,

$\mathrm{d}$ - is the required moisture content $(\%, \mathrm{fw})$.

Subsequently, the SD seeds of each treatment group were divided into two sub-groups. First part of the seeds was taken to the germination tests immediately while the second part was dried back (DB) until the initial seed moisture content (7.4\%) was reached at $25^{\circ} \mathrm{C}$ before the germination test was set up.

The seeds were set to germinate in an incubator running at $25 \pm 0.5^{\circ} \mathrm{C}$ and $70 \pm 5 \% \mathrm{RH}$. Germination tests were set up using a "Factorial Randomized Plots Design" with 200 seeds (i.e., 4 replicates of 50 seeds) in each treatment group. The percentage viability (normal germination rate; NGR) of seeds was determined according to the ISTA Rules (ISTA, 2012). Germination test results were recorded daily until day 14 . Then, responses of organic tomato seeds to priming and dehydration treatments were observed on the bases of different vigour parameters such as mean germination time (MGT), germination index (GI), seedling dry weight (SDW) and seedling vigour index (SVI).

MGT was calculated according to the equation of Ellis and Roberts (1981):

$\mathrm{MGT}=\sum \mathrm{dn} / \sum \mathrm{n}$,

where:

$\mathrm{d}$ : Days counted from the beginning of germination

$\mathrm{n}$ : The number of seeds germinated on day $\mathrm{d}$ (1962):

GI was calculated according to the equation of Maguire

$\mathrm{GI}=\sum \mathrm{n} / \mathrm{d}$,

where:

$\mathrm{n}$ : The number of normal seedlings on day $\mathrm{d}$

$\mathrm{d}$ : Days counted from the beginning of germination

All the normal germinating seedlings in each treatment group were dried at $70{ }^{\circ} \mathrm{C}$ for 24 hours to a constant weight and mean SDW were recorded as $\mathrm{mg}$.

(2004):

SVI was calculated by the equation of Butola and Badola

$$
\begin{aligned}
& \text { SVI }=\text { SDW } / \text { MGT } \times 100, \\
& \text { where: } \\
& \text { SDW: Mean dry weight per seedling }(\mathrm{mg}) \\
& \text { MGT: Mean germination time }(\text { day })
\end{aligned}
$$

\section{Statistical procedures}

The data were subjected to a two-way ANOVA, except the final percentages of normal seedlings were analysed after arcsin transformation. The differences of means were compared by LSD tests at $\mathrm{p} \leq 0.05$, in a JMP 7.0 computer programme. Moreover, the correlations between NGR and the vigour parameters were evaluated in a correlation matrix.

\section{Results}

The changes occurred in seed moisture content following priming and dehydration treatments in organic seeds of tomato cv. 'Rio Grande' are illustrated in Fig. 1. While the moisture content of control seeds was $7.4 \%$, the final seed moisture content rose to $44.5 \%$ following $\mathrm{HP}+\mathrm{SD}$ and varied between 39.5 and $43.4 \%$ following different $\mathrm{OP}+\mathrm{SD}$ treatments. The seed moisture contents of each $\mathrm{DB}$ treatment following either $\mathrm{HP}$ or OP decreased to $7.4 \%$.

Normal germination progress curves (i.e., the cumulative 


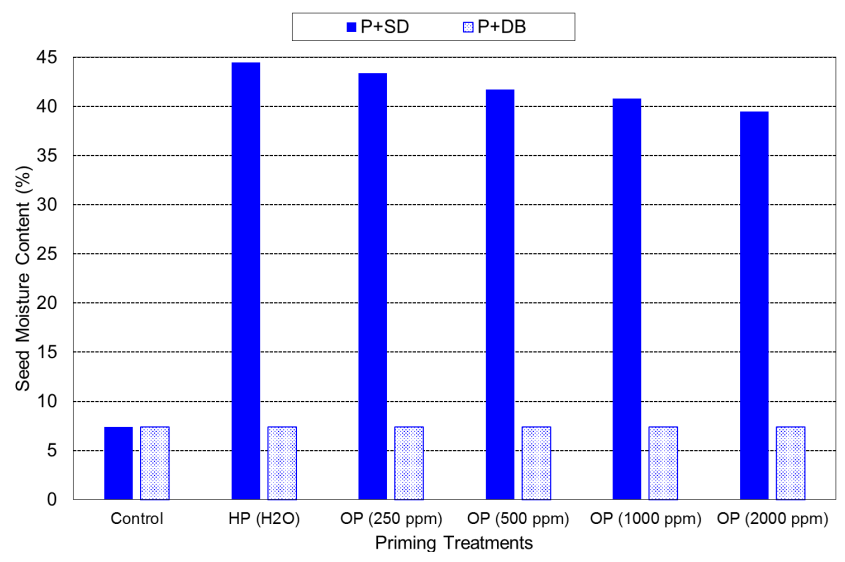

Fig. 1. The changes occurred in seed moisture content following priming and dehydration treatments in organic seeds of tomato cv. 'Rio Grande'

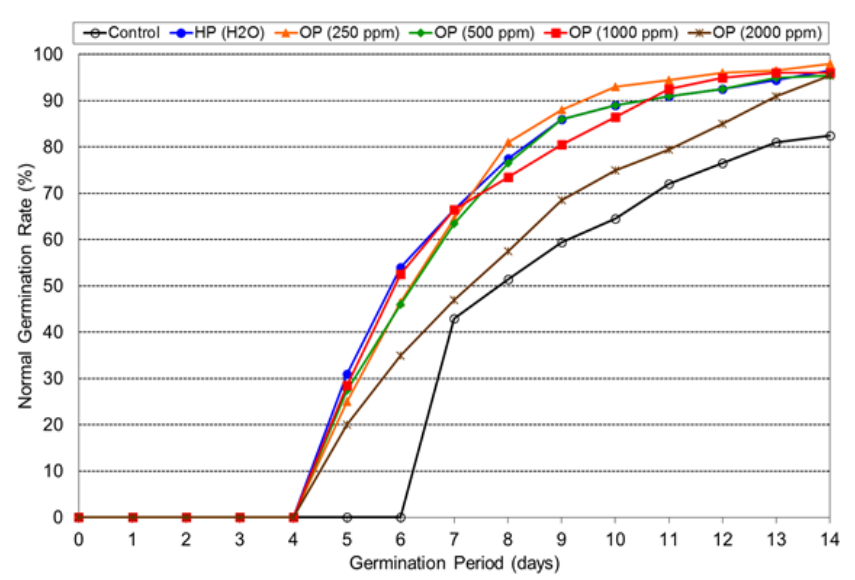

Fig. 3. Normal germination progress curves of organic tomato cv. 'Rio Grande' seeds following priming (HP and OP) $+\mathrm{DB}$ treatments

normal germination curves) of organic tomato seeds following priming (HP and $\mathrm{OP}$ ) and dehydration (SD and $\mathrm{DB})$ treatments are presented in Figs. 2 and 3. It is clear from the results that germination occurred earlier and that the final percentages of normal germination of HP and OP seeds (irrespective of dehydration treatments) were higher relative to the control seeds. However, the best results were obtained from $\mathrm{HP}$ and OP $(250 \mathrm{ppm})+\mathrm{SD}$ and DB treatments (Figs. 2 and 3).

The results shown in Table 1 are convincing evidence that both priming treatments had significant effects $(p \leq 0.05)$ on viability (NGR) and vigour (MGT, GI, SDW and SVI) of organic tomato seeds. However, the effects of dehydration treatments on seed viability and vigour were only significant $(p \leq 0.05)$ for GI and SDW parameters. Furthermore, the effects of the interaction between priming and dehydration treatments were also significant $(p \leq 0.05)$ on seed viability and vigour parameters.

All the priming and dehydration treatments gave better results compared with the control. As a general trend, NGR, GI, SDW and SVI increased whereas MGT decreased depending on HP and OP + SD and DB treatments. When the overall data were assessed, the best results were obtained

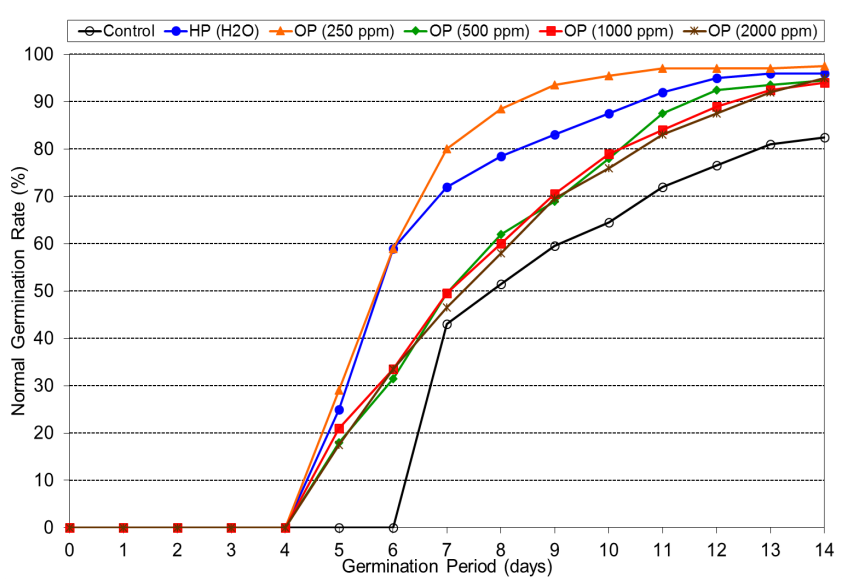

Fig. 2. Normal germination progress curves of organic tomato cv. 'Rio Grande' seeds following priming (HP and OP) + SD treatments

from the HP and OP (250 ppm) followed by either SD or DB treatments for organic tomato seeds (Table 1 ).

All the correlations between NGR and each vigour parameter (MGT, GI, SDW and SVI) were significant $(p \leq 0.05)$ (Table 2). The highest correlation was found between NGR and GI, and this was followed by SVI, MGT and SDW.

\section{Discussion}

To date very little work has been carried out on organic seed hydration (HP and OP) and subsequent dehydration (SD and DB) techniques and also their effects on seed viability and vigour, which are the substantial components of seed quality. Previous studies have shown that both HP (McDonald, 2000; Caseiro et al., 2004; Tajbakhsh et al., 2004; Sivritepe and Teoman, 2014) and OP (Sivritepe and Sivritepe, 2008; Mavi, 2014; Sivritepe et al., 2015) are useful techniques as they cause physiological enhancements and increases in performance of seeds. These positive effects of HP and OP have been demonstrated by the use of different physiological parameters such as NGR (represents seed viability), and MGT, GI, SDW and SVI (represent seed vigour). Our results are in agreement with those of the above mentioned studies.

Dehydration of seeds following priming is of vital importance. In fact, sustainability of the beneficial effects of priming depends on subsequent dehydration conditions. These are temperature, speed (which depends on ambient air, forced air or vacuum drying) and degree of dehydration (i.e., SD and DB) (Pill, 1995; McDonald, 2000; Copeland and McDonald, 2001). Moreover, the effects of the above dehydration conditions on viability and vigour of primed seeds vary depend on species (Pill, 1995; McDonald, 2000), even cultivars within a species (Sivritepe and Şentürk, 2011; Sivritepe et al., 2015). The results of the present study suggested that following HP and OP, the effects of SD and DB on viability and vigour of organic tomato seeds were similar. In other words, the beneficial effects of HP and OP sustained following SD and DB treatments. Besides both dehydration treatments gave better results compared with the control.

To our knowledge, application of organic hydrationdehydration techniques to organic seeds has been lacking in the 
Table 1. The effects of hydropriming and organic priming with different seaweed extract solutions and dehydration treatments on viability and vigour in organic seeds of tomato cv. 'Rio Grande'

\begin{tabular}{|c|c|c|c|c|c|c|}
\hline $\begin{array}{c}\text { Priming } \\
\text { Treatments }\end{array}$ & $\begin{array}{l}\text { Dehydration } \\
\text { Treatments }\end{array}$ & $\begin{array}{l}\text { Normal Germ. } \\
\text { Rate } \\
(\%)\end{array}$ & $\begin{array}{c}\text { Mean } \\
\text { Germ. } \\
\text { Time } \\
\text { (days) }\end{array}$ & $\begin{array}{l}\text { Germ. } \\
\text { Index }\end{array}$ & $\begin{array}{c}\text { Seedling } \\
\text { Dry } \\
\text { Weight } \\
(\mathrm{mg}) \\
\end{array}$ & $\begin{array}{l}\text { Seedling Vigour } \\
\text { Index }\end{array}$ \\
\hline Control & - & $82.5 \mathrm{~d}^{\alpha}$ & $8.6 \mathrm{a}$ & $20.2 \mathrm{~d}$ & $1.67 \mathrm{~g}$ & $19.5 \mathrm{~g}$ \\
\hline \multirow{2}{*}{$\mathrm{HP}\left(\mathrm{H}_{2} \mathrm{O}\right)$} & SD & $96.0 \mathrm{abc}$ & $6.8 \mathrm{e}$ & $30.0 \mathrm{~b}$ & $1.94 \mathrm{a}$ & $28.5 \mathrm{a}$ \\
\hline & DB & $96.5 \mathrm{abc}$ & $6.8 \mathrm{e}$ & $30.1 \mathrm{~b}$ & $1.83 b c$ & $26.3 \mathrm{bc}$ \\
\hline \multirow{2}{*}{ OP (250 ppm) } & SD & $97.5 \mathrm{ab}$ & $6.4 \mathrm{f}$ & $31.6 \mathrm{a}$ & $1.85 \mathrm{~b}$ & $28.8 \mathrm{a}$ \\
\hline & DB & $98.0 \mathrm{a}$ & $6.9 \mathrm{e}$ & $29.6 \mathrm{~b}$ & $1.76 \mathrm{def}$ & $26.6 \mathrm{~b}$ \\
\hline \multirow{2}{*}{ OP (500 ppm) } & SD & $94.5 \mathrm{bc}$ & $8.1 \mathrm{~b}$ & $26.2 \mathrm{c}$ & $1.82 \mathrm{bcd}$ & $23.2 \mathrm{de}$ \\
\hline & DB & $95.5 \mathrm{abc}$ & $7.0 \mathrm{~d}$ & $29.2 \mathrm{~b}$ & $1.70 \mathrm{def}$ & $24.4 \mathrm{~cd}$ \\
\hline \multirow{2}{*}{ OP (1000 ppm) } & SD & $94.0 \mathrm{c}$ & $7.9 \mathrm{~b}$ & $26.3 \mathrm{c}$ & $1.82 \mathrm{bcd}$ & $23.3 \mathrm{de}$ \\
\hline & DB & $96.0 \mathrm{abc}$ & $7.2 \mathrm{~d}$ & $29.7 \mathrm{~b}$ & $1.83 \mathrm{bc}$ & $25.3 \mathrm{bc}$ \\
\hline \multirow{2}{*}{ OP (2000 ppm) } & SD & $95.0 \mathrm{abc}$ & $8.1 \mathrm{~b}$ & $25.9 \mathrm{c}$ & $1.82 \mathrm{bcd}$ & $22.6 \mathrm{ef}$ \\
\hline & DB & $95.5 \mathrm{abc}$ & $8.2 \mathrm{a}$ & $26.1 \mathrm{c}$ & $1.74 \mathrm{def}$ & $21.3 \mathrm{f}$ \\
\hline \multirow{3}{*}{\multicolumn{2}{|c|}{$\begin{array}{c}\text { Priming Treatments (A) } \\
\text { Dehydration Treatments (B) } \\
\text { A x B }\end{array}$}} & * & * & * & * & \multirow{3}{*}{$\begin{array}{c}* \\
\mathrm{~ns} \\
*\end{array}$} \\
\hline & & ns & ns & $*$ & * & \\
\hline & & $*$ & $*$ & * & * & \\
\hline
\end{tabular}

${ }^{a}$ Values not associated with the same letter are significantly different $(\mathrm{p} \leq 0.05)$

* Significant at 0.05 level

ns: Not significant

Table 2. The multivariate correlations between viability (NGR) and vigour parameters (MGT, GI, SDW and SVI) in organic seeds of tomato cv. 'Rio Grande'

\begin{tabular}{|c|c|c|c|c|c|}
\hline Traits & NGR & MGT & GI & SDW & SVI \\
\hline NGR & 1,0000 & & & & \\
\hline MGT & $-0,6953^{*}$ & 1,0000 & & & \\
\hline GI & $0,8898^{*}$ & $-0,9257^{*}$ & 1,0000 & & \\
\hline SDW & $0,6013^{*}$ & $-0,4247$ & $0,5727^{*}$ & 1,0000 & \\
\hline SVI & $0,7284^{*}$ & $-0,9393^{*}$ & $0,9178^{*}$ & $0,6999^{*}$ & 1,0000 \\
\hline
\end{tabular}

literature. Therefore, this study is the first attempt to develop a procedure not only to share the new findings in scientific media but also to introduce it to organic farming regulations of different countries. Furthermore, the results of these experiments suggest that HP and OP could be used both in seed and seedling industries to improve seed quality and performance of organic tomatoes.

\section{Conclusions}

The results indicated that the addition of organic hydration-dehydration techniques to the current procedures of the regulations of organic tomato production could be a useful strategy from different points of view. Application of these techniques to organic tomato seeds could provide faster and more uniform germination as well as earlier seedling establishment. The use of HP and OP as organic hydration and also $\mathrm{SD}$ and $\mathrm{DB}$ as dehydration techniques should further be studied in organic seeds of other agricultural and horticultural species to produce specific protocols. Moreover, possibilities of using other seaweeds and organic materials in organic seed hydration techniques should also be evaluated in organic seeds prior to organic seedling production and/or plant growing. Our studies are in progress to investigate whether the beneficial effects of organic seed hydration-dehydration persist beyond the later growth and development stages of organic tomato plants.

\section{References}

Ashraf M, Foolad MR (2005). Pre-sowing seed treatment-a shotgun approach to improve germination, plant growth, and crop yield under saline and non-saline conditions. Advances in Agronomy 88:223-271.

Blunden G (1991). Agricultural uses of seaweeds and seaweed extracts. In: Guiry MD, Blunden G (Eds). Seaweed resources in Europe: Uses and potential.John Wiley and Sons, Chichester pp 65-81.

Butola JS, Badola HK (2004). Effect of pre-sowing treatment on seed germination and seedling vigour in Angelica glauca, a threatened medicinal herb. CurrentScience 87(6):796-799.

Caseiro R, Bennett MA, Marcos-Filho J (2004). Comparison of three priming techniques for onion seed lots differing in initial seed quality. Seed Science and Technology 32:365-375.

Copeland LO, McDonald MB (2001). Principles of seed science and technology. Kluwer Academic Publishers, Massachusetts, USA.

Craigie JS (2011). Seaweed extract stimuli in plant science and agriculture. Journal of Applied Phycology 23:371-393.

Ellis RH, Roberts EH (1981). The quantification of ageing and survival in orthodox seeds.Seed Science and Technology 9:373-409.

Hussain M, Farooq M, Basra SMA (2006). Ahmad N. Influence of seed priming techniques on the seedling establishment, yield and quality of 
hybrid sunflower. International Journal of Agriculture and Biology 8:14 18.

IFOAM (2011). IFOAM position paper: The use of organic seed and plant propagation material in organic agriculture. IFOAM Head Office, Bonn, Germany.

ISTA (2012). International Rules for Seed Testing. Edition 2012. International Seed Testing Association, Bassersdorf,Switzerland.

Lutts S, Benincasa P, Wojtyla L, Kubala S, Pace R, Lechowska K, Quinet M, Garnczarska M (2016). Seed priming: New comprehensive approaches for an old empirical technique. In: Araujo S, Balestrazzi A (Eds). New challenges in seed biology - Basic and translational research driving seed technology.InTechOpen, Rijeka, Croatia pp 1-46.

Maguire JD (1962). Speed of germination-aid in selection and evaluation for seedling emergence and vigor. CropScience 2:176-177.

Mavi K (2014). Use of extract from dry marigold (Tagetes spp.) lowers to prime eggplant (Solanum melongena L.) seeds. Acta Scientiarum Polonorum Horticulture 13(4):3-12.

McDonald MB (2000). Seed priming. In: Black M, Bewley JD (Eds). Seed technology and its biological basis. Sheffield Academic Press, Sheffield, pp287-325.

Pill WG (1995). Low water potential and presowing germination treatments to improve seed quality. In: Basra AS (Ed). Seed quality. Food Products Press, Binghamton, NY pp 319-359.

Senn TL (1987). Seaweed and plant growth. Clemson University, Clemson, USA.

Sivritepe HÖ (1992). Genetic deterioration and repair in pea (Pisum sativum L.) seeds during storage. $\mathrm{PhD}$ Thesis, University of Bath, England.
Sivritepe HÖ, Şentürk B (2011). Biber tohumlarının fizyolojik olarak iyileştirilmesi için su ve tuz çözeltileri ile yapılan priming ve kurutma uygulamalarının karşlaşturlması [A comparison of hydro and halopriming with dehydration treatments for physiological enhancement of pepper seeds]. Uludağ Üniversitesi Ziraat Fakültesi Dergisi 25(1):53-64.

Sivritepe HÖ, Teoman S (2014). Patlıcan tohumlarının fizyolojik olarak iyileştirilmesinde kullanılan farklı hidrasyon ve kurutma uygulamalarının karşlaştırması [Comparison of different hydration-dehydration treatments in physiologically improvement of eggplant seeds]. 10. Sebze TarımıSempozyumu, 02-04Eylül, Tekirdağ, Türkiye.

Sivritepe HÖ, Şentürk B, Teoman S (2015). Biber tohumlarında yapilan organik priming ve kurutma uygulamalan fide kalitesi ve performansinı iyileşirmektedir [Organic priming and dehydration treatments in pepper seeds improve seedling quality and performance]. Uludağ ÜniversitesiZiraat Fakültesi Dergisi29(2):106-117.

Sivritepe N, Sivritepe HÖ (2008). Organic priming with seaweed extract (Ascophyllum nodosum) affects viability of pepper seeds. Asian Journal of Chemistry20(7):5689-5694.

Tajbakhsh M, Brown PH, Gracie AJ, Spurr CJ, Donovan N, Clark RJ (2004). Mitigation of stunted root abnormality in onion (Allium cepa L.) using seed priming treatments. Seed Science and Technology 32:683-692.

Varier A, Vari AK, Dadlani M (2010). The subcellular basis of seed priming. Current Science 99:450-456. 